\title{
The effect of antioxidant drugs on veterinary and sanitary parameters of cow's milk
}

\author{
Lidia Kashirina ${ }^{1, *}$, Konstantin Ivanischev, and Kirill Romanov \\ ${ }^{1}$ Ryazan State Agrotechnological University named after P.A. Kostychev, 390044 Ryazan, Russia
}

\begin{abstract}
The article presents the results of experimental studies to determine the effect of antioxidant drugs "Butofan" and "E-selenium" on veterinary and sanitary parameters of cows' milk obtained in the period after calving. Childbirth is characterized by a stressful physiological state of the body and a large amount of lipid peroxidation (LPO) products are formed in the blood of cows, which have a negative depleting effect on the body and, naturally, on the quality of milk, since it is a blood product. To enhance the work of the body's own antioxidant system, since it is not always enough to neutralize LPO products, antioxidant drugs are used. It is necessary to determine veterinary and sanitary parameters in milk obtained under the influence of any drugs, since it is used in human nutrition. For this purpose, experimental studies were carried out on analogous dairy cows in one of the farms of Ryazan region. The cows were divided into three groups: the control and two experimental ones. The control group of animals was intact, the cows of the experimental groups received antioxidant preparations: the first one got "E-selenium" and the second one got "Butofan". The research results showed that the milk yield of cows in the experimental groups was higher compared to the control. The quality parameters of milk in the experimental groups of cows were better in terms of fat content, protein content, density and acidity. Cow's milk under the influence of antioxidant drugs was biologically complete and environmentally friendly.
\end{abstract}

\section{Introduction}

Antioxidants reduce the level of free radical oxidation in the body and inhibit oxidation that damages cells. The widespread antioxidants include some vitamins, carotenoids, coenzyme Q 10, etc. Antioxidant drugs are recommended to be administered to productive animals during periods of stressed physiological state, when a large amount of lipid peroxidation (LPO) products are formed in the body, in particular, before and after childbirth periods $[1,2]$. The body's own antioxidant system does not always cope with neutralization of a large amount of the formed LPO intermediate products, which have a negative effect on the body. In order to help the body of cows to recover in a shorter period of time after giving birth and to increase productivity, since it is known that in the postpartum period the milk yield of cows increases, this has been proven by a number of

\footnotetext{
${ }^{*}$ Corresponding author: kashirina@rgatu.ru
} 
studies $[3,4]$. It is known that any food product obtained from animals under the influence of drugs, since it is directly related to human health, is subject to veterinary and sanitary assessment, therefore the question of the effect of antioxidant drugs on the quality parameters of milk is relevant $[1,5]$.

The purpose of the research is to study the effect of antioxidant drugs "Butofan" and "Eselenium" on the veterinary and sanitary parameters of cow's milk after calving.

\section{Materials and methods}

Experimental studies were carried out in one of the farms of Ryazan region with cowsanalogues of the black-and-white breed in the postpartum period, beginning from the third month after calving in the midst of lactation. Animals were divided into three groups: the control and two experimental ones, 4 heads each, with an average productivity for the previous lactation of $4,958 \pm 17.6 \mathrm{~kg}$ of milk. The animals were fed three times a day and had a free access to water. The diet corresponded to the RAAS standards for dairy cows [6].

Intact cows received a farm diet (FD). Experimental cows also got antioxidant drugs: it was "E-selenium" in experimental group 1 and "Butofan" in experimental group 2. The experiment scheme is shown in Table 1.

The composition of the antioxidant drugs was as follows:

- "E-selenium" contains active the following ingredients: tocopherol acetate $-50 \mathrm{mg} / \mathrm{ml}$, sodium selenite $-0.5 \mathrm{mg} / \mathrm{ml}$ and additional components: HS15 solutol, distilled water and benzyl alcohol;

- $1 \mathrm{ml}$ of "Butofan" contains $100 \mathrm{mg}$ of butafosfan and $0.05 \mathrm{mg}$ of cyanocobalamin.

Table 1. Scheme of the experiment.

\begin{tabular}{|c|c|c|}
\hline Group & $\begin{array}{c}\text { Number } \\
\text { of } \\
\text { animals }\end{array}$ & Doses and frequency of the drug use \\
\hline Control & 4 & Intact animals (FD) \\
\hline $\begin{array}{c}\text { Experimental } \\
1\end{array}$ & 4 & "E-selenium" i.m. at a dose of $10 \mathrm{ml}$ per head once a month \\
for four months
\end{tabular}

Veterinary and sanitary parameters in milk were studied individually on a monthly basis using the control milking method. The average sample from each cow was formed from samples taken over three milkings. Veterinary and sanitary examination of milk was carried out by generally accepted methods in accordance with GOST [7-10]. The mass fraction of fat and protein was determined using the "Laktan 1-4" device.

The research results were subjected to statistical processing according to t-test method. The difference between the three groups of cows was studied, as well as that between the periods of sampling. The difference was considered significant at $\mathrm{P}<0.05$. The calculations were performed using "Statistics" and "Microsoft Office Excel 2003" computer programs.

\section{Results and discussion}

For better informational content about the results of the action of antioxidant drugs, the parameters of the daily milk yield of cows, obtained in the third month in the "height" of lactation are presented. It was found that the daily milk yield of cows in the experimental groups was higher than that in the control (Table 2). It increased by $0.7 \%$ in experimental group 1 and by $23.13 \%$ in experimental group 2 in comparison with the control. "Butofan", which was used in Experimental group 2, proved itself to be the best. It had a more 
powerful effect on animals, so the milk yield of cows increased by 6.0 liters compared with experimental group 1 and by 6.2 liters compared to the control. In the subsequent months of lactation, markers of milk yield in the experimental groups gradually came to the same level and exceeded the parameters of the control group.

The fat content of milk was also at a higher level in the experimental groups. It was $+4.7 \%$ in experimental group 1 and $+6.42 \%$ in experimental group 2 , compared with the control. This trend continued to persist in the subsequent months of lactation.

A significant parameter that determines the quality of milk is the protein content. The protein content was higher in the milk obtained from the cows of experimental group 2, where "Butofan" was used in months 4 and 5 of lactation, compared to the control group and experimental group 1 .

Table 2. Milk productivity of cows $(n=4)$.

\begin{tabular}{|c|c|c|c|}
\hline Group & Daily milk yield, kg & Fat content, \% & $\begin{array}{c}\text { Protein content, } \\
\%\end{array}$ \\
\hline \multicolumn{4}{|c|}{ 3rd month of lactation } \\
\hline Control & $26.8 \pm 11.11$ & $3.58 \pm 0.26$ & $3.14 \pm 0.08$ \\
\hline Experimental 1 & $27.0 \pm 6.68$ & $3.75 \pm 0.19^{*}$ & $3.11 \pm 0.07$ \\
\hline Experimental 2 & $33.0 \pm 10.92^{* *}$ & $3.81 \pm 0.31^{* *}$ & $3.08 \pm 0.14$ \\
\hline \multicolumn{4}{|c|}{ 4th month of lactation } \\
\hline Control & $23.4 \pm 4.96$ & $3.57 \pm 0.21$ & $3.12 \pm 0.07$ \\
\hline Experimental 1 & $24.7 \pm 5.65^{*}$ & $3.75 \pm 0.07$ & $3.04 \pm 0.01$ \\
\hline Experimental 2 & $24.2 \pm 6.14$ & $3.77 \pm 0.29$ & $3.15 \pm 0.09$ \\
\hline \multicolumn{4}{|c|}{5 th month of lactation } \\
\hline Control & $24.5 \pm 9.12$ & $3.65 \pm 0.15$ & $3.11 \pm 0.07$ \\
\hline Experimental 1 & $25.0 \pm 6.05$ & $3.77 \pm 0.08$ & $3.08 \pm 0.03$ \\
\hline Experimental 2 & $24.8 \pm 8.54$ & $3.80 \pm 0.23^{* *}$ & $3.14 \pm 0.07$ \\
\hline
\end{tabular}

Note: conventional signs give the reliability of the difference in parameters compared to the control group $*-\leq 0.05, * *-\mathrm{p} \leq 0.01, * * *-\mathrm{p} \leq 0.001$.

The milk under study had a pleasant taste and specific smell. It had a uniform white color and no fat sediment was observed. There were no mucus or protein flakes in the milk, and the liquid was not viscous. Antioxidant drugs used in the experiment did not have any significant effect on the change in milk density (Fig. 1).

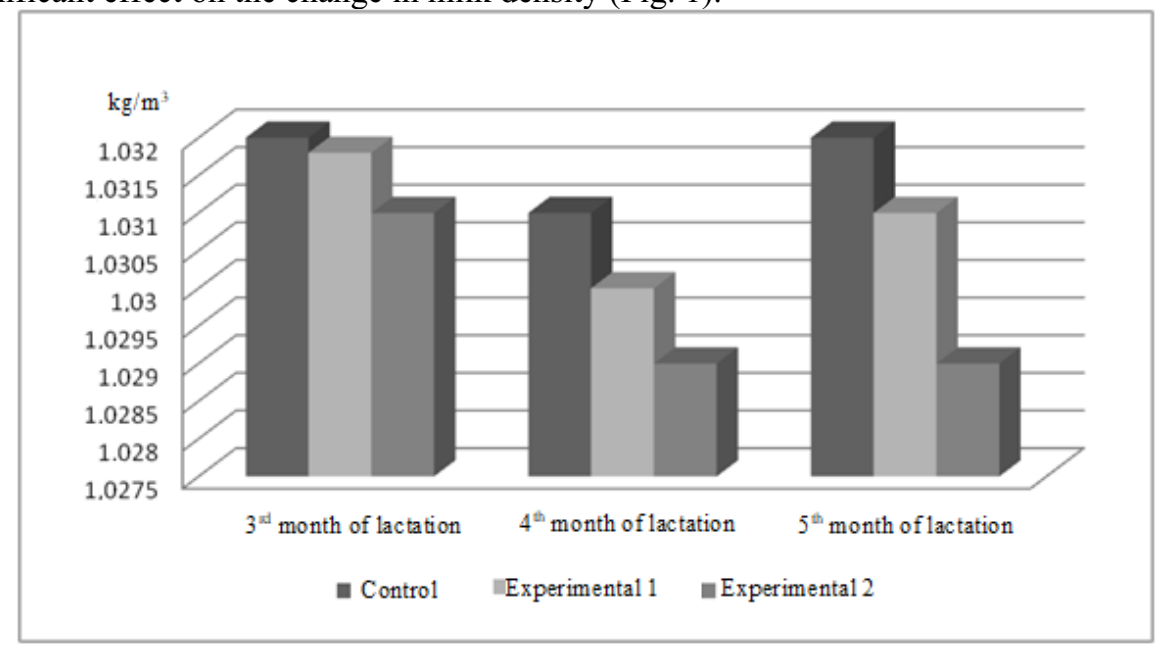

Fig. 1. Relative dynamics of milk density, $\mathrm{kg} / \mathrm{m}^{3}$. 
The density of milk is of decisive importance in determining its quality, since it indicates its naturalness. The higher the fat content of milk is, the lower its density is. The density index is influenced by the content of minerals, protein and carbohydrates in it. Therefore, the density parameter depends on the general condition of the animal's body.

It was found that the density parameter in the milk of cows in the control group was higher than that in the experimental groups. By months of lactation, there was a decrease in this parameter in the milk of cows in the experimental groups. This, of course, was associated with an increase in fat content in milk of animals in the experimental groups compared to the control.

The acidity of milk is important in determining its quality. It was found that the use of antioxidant drugs influenced the value of this parameter. Thus, the acidity of milk in the third and fourth months of lactation, when the defense mechanisms of the antioxidant system of the body were activated, decreased in the experimental groups under the influence of "E-selenium" and "Butofan" compared to the group of intact animals (Fig. 2).

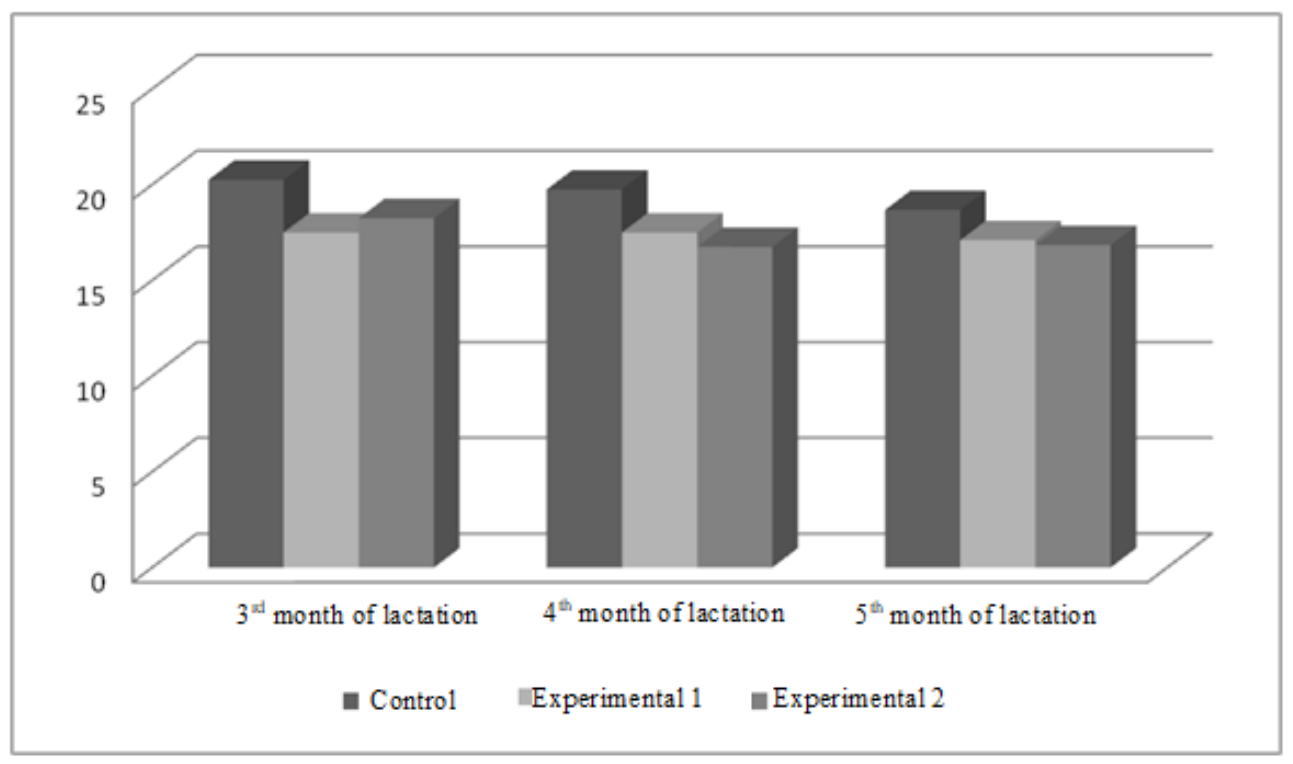

Fig. 2. Relative dynamics of milk acidity, ${ }^{0} \mathrm{~T}$.

The decrease in milk acidity in experimental group 1 having "E-selenium" was $13.6 \%$ in the third month of lactation and $11.4 \%$ in the fourth month compared to the control group. The decrease in milk acidity in experimental group 2 having "Butofan" was $9.8 \%$ in the third month of lactation and $15.2 \%$ in the fourth month in relation to the control.

From the point of view of veterinary and sanitary examination for milk, the most significant is the study of microbiological and physicochemical parameters (Table 3). From the data in Table 3 it follows that they were subject to minor changes that did not exceed the permissible limits and did not violate the requirements of TR CU 033/2013 Technical Regulations of the Customs Union "On the safety of milk and dairy products" $[7,8]$. 
Table 3. Results of microbiological and physicochemical studies of cow milk $(n=4)$.

\begin{tabular}{|c|c|c|c|c|}
\hline Parameters & $\begin{array}{c}\text { The norm } \\
\text { established by } \\
\text { TR CU } \\
033 / 2013\end{array}$ & Control & Experimental 1 & Experimental 2 \\
\hline \multicolumn{5}{|c|}{$3^{\text {rd }}$ month of lactation } \\
\hline $\begin{array}{l}\text { Mass fraction } \\
\text { of MSNF, } \%\end{array}$ & $\begin{array}{c}\text { Not less than } \\
8.2\end{array}$ & $8.41 \pm 0.15$ & $8.48 \pm 0.15$ & $8.49 \pm 0.15$ \\
\hline $\begin{array}{l}\text { QMAFanM, } \\
\text { CFU / } \mathrm{cm}^{3}\end{array}$ & $\begin{array}{c}\text { Not more than } \\
4 \times 10^{5} \\
\end{array}$ & $2.8 \times 10^{5}$ & $2.6 \times 10^{4}$ & $2.5 \times 10^{4}$ \\
\hline $\begin{array}{c}\text { Somatic cell } \\
\text { content } \\
\text { in } 1 \mathrm{~cm}^{3}\end{array}$ & $\begin{array}{c}\text { Not more than } \\
7.4 \times 10^{5}\end{array}$ & $3.6 \times 10^{5} \pm 0.37 \times 10^{5}$ & $3.1 \times 10^{5} \pm 0.31 \times 10^{5}$ & $2.8 \times 10^{5} \pm 0.30 \times 10^{5}$ \\
\hline $\begin{array}{l}\text { Pathogenic, } \\
\text { including } \\
\text { salmonella }\end{array}$ & $\begin{array}{l}\text { Not allowed } \\
\text { in } 25.0 \mathrm{~cm}^{3}\end{array}$ & $\begin{array}{l}\text { Not allowed } \\
\text { in } 25.0 \mathrm{~cm}^{3}\end{array}$ & $\begin{array}{l}\text { Not allowed } \\
\text { in } 25.0 \mathrm{~cm}^{3}\end{array}$ & $\begin{array}{l}\text { Not allowed } \\
\text { in } 25.0 \mathrm{~cm}^{3}\end{array}$ \\
\hline \multicolumn{5}{|c|}{$4^{\text {th }}$ month of lactation } \\
\hline $\begin{array}{l}\text { Mass fraction } \\
\text { of MSNF, \% }\end{array}$ & $\begin{array}{c}\text { Not less than } \\
8.2\end{array}$ & $8.40 \pm 0.15$ & $8.52 \pm 0.15$ & $8.55 \pm 0.15$ \\
\hline $\begin{array}{l}\text { QMAFanM, } \\
\text { CFU / } \mathrm{cm}^{3}\end{array}$ & $\begin{array}{c}\text { Not more than } \\
4.9 \times 10^{5}\end{array}$ & $3.1 \times 10^{5}$ & $4.7 \times 10^{4}$ & $4.3 \times 10^{4}$ \\
\hline $\begin{array}{c}\text { Somatic cell } \\
\text { content } \\
\text { in } 1 \mathrm{~cm}^{3}\end{array}$ & $\begin{array}{c}\text { Not more than } \\
7.6 \times 10^{5}\end{array}$ & $3.7 \times 10^{5} \pm 0.36 \times 10^{5}$ & $3.2 \times 10^{5} \pm 0.27 \times 10^{5}$ & $2.6 \times 10^{5} \pm 0.24 \times 10^{5}$ \\
\hline $\begin{array}{l}\text { Pathogenic, } \\
\text { including } \\
\text { salmonella }\end{array}$ & $\begin{array}{l}\text { Not allowed } \\
\text { in } 25.0 \mathrm{~cm}^{3}\end{array}$ & $\begin{array}{l}\text { Not allowed } \\
\text { in } 25.0 \mathrm{~cm}^{3}\end{array}$ & $\begin{array}{l}\text { Not allowed } \\
\text { in } 25.0 \mathrm{~cm}^{3}\end{array}$ & $\begin{array}{l}\text { Not allowed } \\
\text { in } 25.0 \mathrm{~cm}^{3}\end{array}$ \\
\hline \multicolumn{5}{|c|}{$5^{\text {th }}$ month of lactation } \\
\hline $\begin{array}{l}\text { Mass fraction } \\
\text { of MSNF, \% }\end{array}$ & $\begin{array}{c}\text { Not less than } \\
8.2\end{array}$ & $8.38 \pm 0.15$ & $8.47 \pm 0.15$ & $8.60 \pm 0.15$ \\
\hline $\begin{array}{l}\text { QMAFanM, } \\
\mathrm{CFU} / \mathrm{cm}^{3}\end{array}$ & $\begin{array}{c}\text { Not more than } \\
4.9 \times 10^{5}\end{array}$ & $2.7 \times 10^{5}$ & $3.6 \times 10^{4}$ & $3.7 \times 10^{4}$ \\
\hline $\begin{array}{c}\text { Somatic cell } \\
\text { content } \\
\text { in } 1 \mathrm{~cm}^{3} \\
\end{array}$ & $\begin{array}{c}\text { Not more than } \\
7.6 \times 10^{5}\end{array}$ & $3.8 \times 10^{5} \pm 0.39 \times 10^{5}$ & $2.6 \times 10^{5} \pm 0.25 \times 10^{5}$ & $2.8 \times 10^{5} \pm 0.24 \times 10^{5}$ \\
\hline $\begin{array}{l}\text { Pathogenic, } \\
\text { including } \\
\text { salmonella }\end{array}$ & $\begin{array}{l}\text { Not allowed } \\
\text { in } 25.0 \mathrm{~cm}^{3}\end{array}$ & $\begin{array}{l}\text { Not allowed } \\
\text { in } 25.0 \mathrm{~cm}^{3}\end{array}$ & $\begin{array}{l}\text { Not allowed } \\
\text { in } 25.0 \mathrm{~cm}^{3}\end{array}$ & $\begin{array}{l}\text { Not allowed } \\
\text { in } 25.0 \mathrm{~cm}^{3}\end{array}$ \\
\hline
\end{tabular}

QMAFAnM CFU is the number of mesophilic aerobic and facultatively anaerobic microorganisms. It is a test for microbial safety and indicates the size of the group, which may contain pathogens and microorganisms that affect milk spoilage. This parameter characterizes quality, freshness and therefore safety. In all periods of milk research, these parameters from cows of different groups did not deviate from the norm.

One of the main parameters of milk safety, in addition to bacterial contamination, is the content of somatic cells. Somatic cells are part of all body tissues. In the process of vital activity in the body, the processes of regeneration and renewal of cellular structures and the cells themselves take place, as these changes take place in the tissues of the udder of cows. Dead cells from the glandular cells of the udder and milk ducts are excreted in milk.

The results of microbiological and physicochemical studies of milk from cows made it possible to conclude that all analyzed parameters were within the limits of the norms in accordance with the requirements of the CU TR $[9,10]$. They changed insignificantly by 
groups, but they were slightly less in milk from cows from the experimental groups who received antioxidant drugs.

\section{Conclusions}

"Oxidative stress" occurs in animals after birth. The introduction of antioxidant drugs "Eselenium" and "Butofan" into the body of cows during this period stimulated the work of their own antioxidant system, helping to resist oxidative stress by stopping lipid oxidation. Antioxidant drugs are transferred from the blood to the cells of the udder alveoli using specific receptor proteins and block LPO processes in them. This, in turn, affects the change in productivity, which is expressed in an increase in milk yield and an improvement in the quality composition of milk. It was found that LPO processes in the body of cows also influenced the veterinary and sanitary parameters of milk, improving the quality parameters. The content of fat and protein in milk increased while reducing acidity and density, thus improving veterinary and sanitary parameters. The milk obtained with the use of antioxidants was biologically complete and environmentally friendly.

\section{References}

1. L. Kashirina, K. Ivanischev, K. Romanov, Int. scientific-practical conference: Agriculture and food security: technology, innovation, markets, human resources (FIES 2019), 2019.

2. L. Kashirina, K. Ivanischev, K. Romanov, E3S Web of Conferences, 176, 02001(2020)

3. I.A. Zbarovskiy, M.V. Bannikov, Monthly Sci. J. 3, 18 (2014)

4. B. Kucsunska, T. Nalecs-Taruacka, Annals of Warsaw Agr. Univ. 289 (2009)

5. V.S. Ulitko, S.P. Lifanova, Herald of Ulyanovsk State Agricult. Acad. 2 (2014)

6. A.P. Kalashnikov, V.I. Fisinina, V.V. Scheglova, N.I. Kleimenova, Norms and rations for feeding farm animals (Moscow, 2003)

7. GOST 28283-2015 "Cow's milk. Method for sensory evaluation of taste and smell".

8. GOST 3624-92 "Milk and dairy products. Titrimetric methods for determining acidity"

9. GOST 31450-2013 "Drinking milk. Technical conditions"

10. TR CU 033/2013 "Technical regulations of the Customs Union" On the safety of milk and dairy products" 